
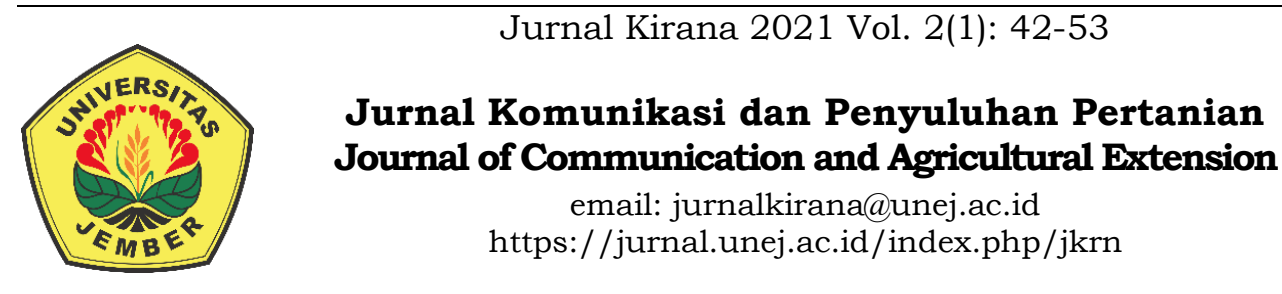

Jurnal Kirana 2021 Vol. 2(1): 42-53

Jurnal Komunikasi dan Penyuluhan Pertanian Journal of Communication and Agricultural Extension

email: jurnalkirana@unej.ac.id

https://jurnal.unej.ac.id/index.php/jkrn

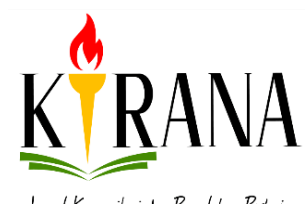

Jurnal Komunikasi dan Penyuluhon Pertanian

\title{
Peran Wanita dan Relasi Gender dalam Keluarga Buruh Tani Wanita \\ di Regu Tanam Mulyo Asri Desa Pontang Kecamatan Ambulu Kabupaten Jember
}

\section{The Roles of Women and Gender Relationships in the Family of Female Farmer Workers in the Mulyo Asri Planting Team Pontang Village Ambulu District Jember Regency}

\section{Aulia Syifa Abdillah ${ }^{\circledR}$ dan Diah Puspaningrum²}

${ }^{1}$ Program Studi Agribisnis Fakultas Pertanian Universitas Jember

2 Program Studi Penyuluhan Pertanian Fakultas Pertanian Universitas Jember

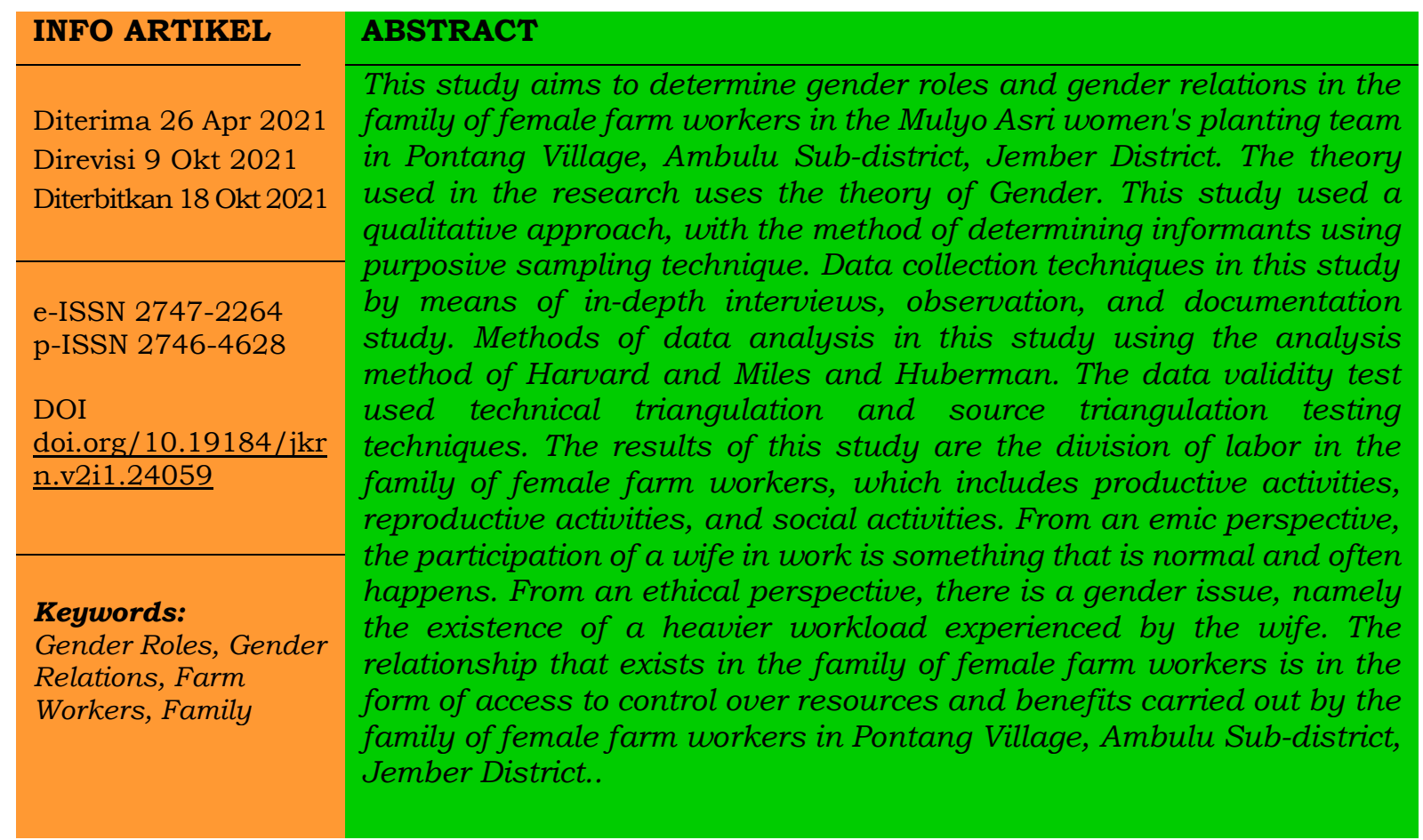

$凶$ Penulis Koresponden :

E-mail : asyifa118@gmail.com 


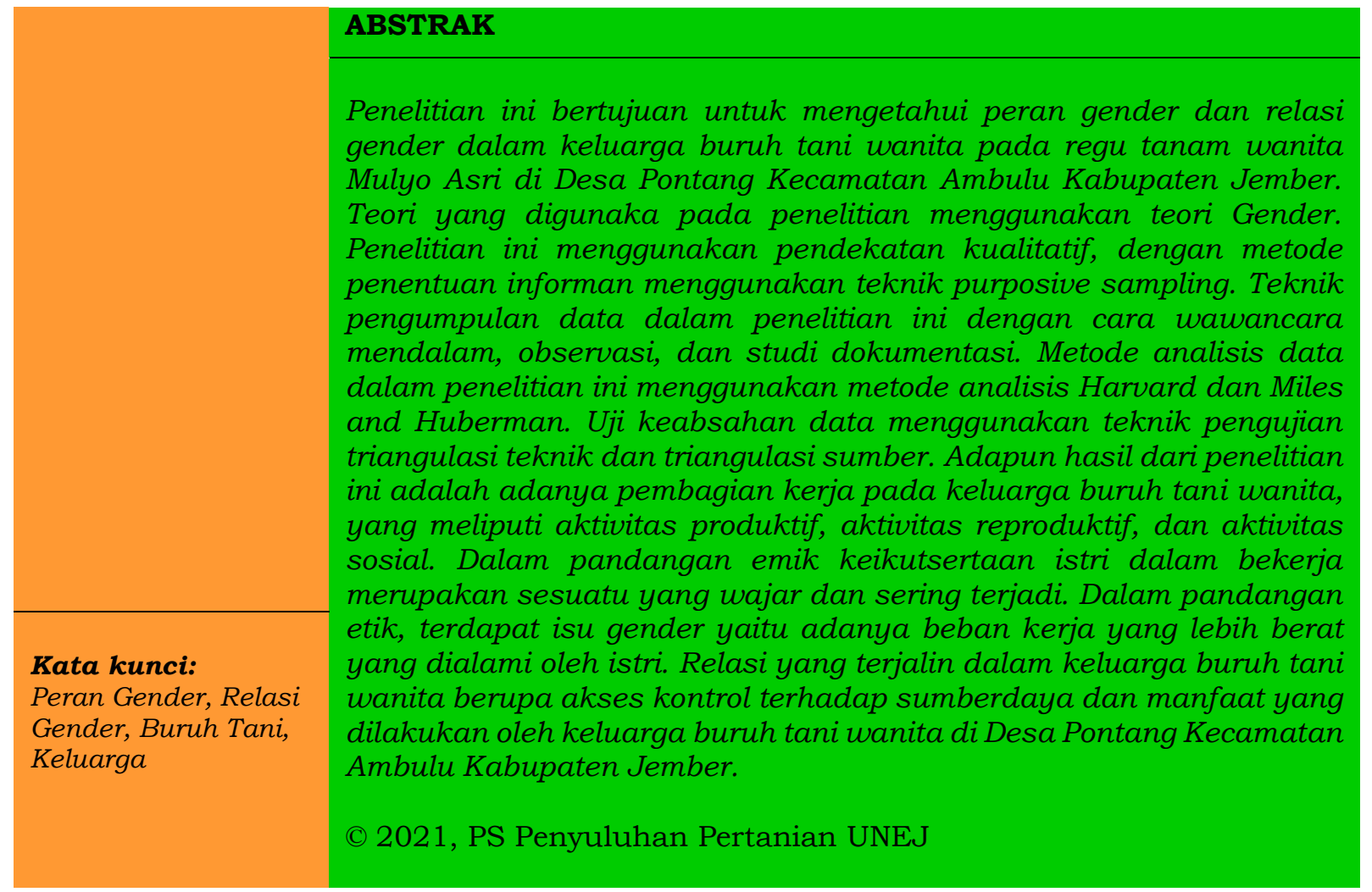

\section{PENDAHULUAN}

Pembudidayaan serta pengelolaan sub sektor dengan baik merupakan salah satu kunci keberhasilan dari suatu usahatani. Menurut Manyamsari \& Mujiburrahmad, (2014), usahatani memiliki unsur-unsur yang selalu melekat dan tidak dapat dipisahkan, unsur tersebut meliputi lahan, modal, tenaga kerja, dan manajemen pengelolaan. tenaga kerja ialah salah satu unsur penting dalam usahatani. Tenaga kerja itu sendiri dibedakan menjadi dua yaitu tenaga kerja keluarga dan tenaga kerja dari luar keluarga. Tenaga kerja keluarga bisaanya terdiri atas petani beserta keluarganya, sedangkan tenaga kerja dari luar keluarga bisaanya ialah masyarakat atau penduduk sekitar. Tenaga kerja dari luar keluarga salah satunya yaitu buruh tani. (Suratiyah, 2015)

Menurut Harahap, I, P, Rosnita, \& Yulida, (2016), buruh tani wanita bisaanya bekerja dikarenakan faktor ekonomi, buruh tani wanita tersebut ingin membantu mencari penghasilan dari bekerja sebagai buruh di lahan pertanian. Buruh tani wanita pada dasarnya dalam hal ini memiliki dua posisi yaitu dalam pekerjaan rumah tangga dan pekerjaan yang dapat menghasilkan pendapatan langsung. Buruh tani wanita memiliki tugas dan tanggung jawab sebagai ibu rumah tangga yang berkewajiban untuk merawat anak dan suami serta mengurus rumah dan dikarenakan perekonomian buruh tani wanita membantu mencari nafkah tambahan.

Menurut penelitian yang dilakukan oleh Suparman, (2017), dalam keluarga terdapat faktor intern dan faktor ekstern yang wanita buruh tani melakukan peran ganda. Faktor internnya yaitu pendapatan suami tidak dapat mencukupi kebutuhan sehari-hari, ditambah dengan pengeluaran dan jumlah tanggungan dalam keluarga, sedangkan faktor eksternnya yaitu lingkungan sekitar yang terdapat lahan pertanian yang banyak membutuhkan tenaga buruh tani dan pedidikan yang rendah serta 
tidak memiliki keterampilan yang memadai sehingga tidak ada luang untuk bekerja dibidang lain. Menurut Meliala, W, Harmona, \& Humaizi, (2019), para wanita yang ikut bekerja sebagai, mereka tidak melupakan tugas dan tanggung jawab seperti mengatur dan mengurus rumah tangga, memasak, membersihkan rumah, dan lain sebagainya.

Desa Pontang tersebut merupakan salah satu desa di Kecamatan Ambulu yang dapat dikatakan cukup maju terutama di bidang pertanian. Mayoritas masyarakat di Desa Pontang tersebut bekerja di bidang pertanian. Desa pontang memiliki kelembagaan kelompok tani yang bernama kelompok tani Budi Margo Mulyo II. Pada tahun 2013, Kelompok Tani Budi Margo Mulyo II mendapatkan sebuah program yang diberikan oleh penyuluh, program tersebut yaitu program penanaman sistem jajar legowo. Penanaman jajar legowo tentunya membutuhkan ketelitian dan ketelatenan, sehingga Kelompok Tani Budi Margo Mulyo II berinisiatif untuk membentuk suatu regu tanam wanita yang diberi nama Mulyo Asri. Penanaman dilakukan oleh 20 anggota wanita Kelompok Tani Budi Margo Mulyo II. Pada tahun 2019 Ketua Kelompok Tani Budi Margo Mulyo II yaitu Bapak Rohmat mengajak 10 buruh tani wanita untuk bergabung dalam regu tanam wanita Mulyo Asri.

Buruh tani yang bergabung dalam regu tanam Mulyo Asri tersebut tentunya harus bisa membagi waktu antara kewajibannya sebagai seorang istri dan ibu, membagi waktu dengan pekerjaannya, dan membagi waktu dengan kegiatan di regu tanam Mulyo Asri. Buruh tani wanita memiliki kewajiban dalam mengurus rumah tangganya seperti memasak, membersihkan rumah, mencuci, dan kewajiban wanita lainnya. Pada dasarnya wanita tidak diwajibkan untuk membantu mencari nafkah untuk keluarga, namun dikarenakan faktor ekonomi sehingga buruh tani wanita pun bekerja demi mencukupi kebutuhan rumah tangga yang semakin mahal. Gaji atau upah yang dimiliki suami tidak cukup untuk memenuhi kebutuhan, hal tersebut membuat buruh tani wanita bekerja. Lingkungan disekitar buruh tani wanita juga mempengaruhi wanita dalam bekerja sebagai buruh tani karena dilingkungannya terdapat lahan pertanian yang banyak membutuhkan tenaga buruh tani, ditambah lagi dengan pendidikan yang rendah serta tidak memiliki keterampilan yang memadai sehingga tidak ada peluang untuk bekerja dibidang lain (Suparman, 2017).

Padatnya aktivitas yang dijalankan oleh buruh tani wanita tersebut tentunnya membutuhkan manajemen waktu yang baik. Semua aktivitas yang dilakukan oleh buruh tani wanita pun tentunya atas persetujuan dari pihak kepala keluarga atau suami, hal tersebut dikarenakan suami lah yang memiliki kekuasaan tertinggi dalam sebuah keluarga. Keluarga buruh tani wanita tentunya memiliki relasi didalamnya, relasi tersebut seperti hubungan relasi antara suami dan istri, orang tua dan anakanaknya, serta relasi antar anak. Suatu relasi dalam keluarga sebagian besar terdapat perbedaan antara laki-laki dan wanita. Bisaanya dalam sebuah keluarga tentunya peran laki-laki (suami) lah yang memiliki kekuasaan dalam rumah tangga, sedangkan wanita (istri) memiliki peran sekunder sehingga semua keputusan dan tanggungjawab atas keluarga berada ditangan laki-laki Meskipun buruh tani wanita telah memiliki pekerjaan dan penghasilan sendiri, tetapi dalam suatu keluarga wanita tetap harus patuh terhadap suaminya dan tetap menuruti apapun keputusan dari suaminya (Sintia \& Mardhiah, 2020). 
Berdasarkan fenomena tersebut peneliti tertarik untuk melakukan penelitian terhadap buruh tani wanita yang tergabung dalam regu tanam Mulyo Asri, sehingga peneliti mendapatkan beberapa rumusan masalah yaitu (1) bagaimana peran gender dalam keluarga buruh tani wanita dan (2) bagaimana relasi gender dalam keluarga buruh tani wanita di Desa Pontang Kecamatan Ambulu Kabupaten Jember. Harapan peneliti dari fenomena tersebut yaitu tidak terjadi ketimpangan gender dalam keluarga buruh tani wanita, sedangkan realita yang terjadi di lapang yaitu adanya ketimpangan gender yaitu beban kerja berlebih yang dialami oleh para istri dalam keluarga buruh tani wanita.

\section{METODE PENELITIAN}

Penentuan pengambilan daerah penelitian dilakukan dengan cara sengaja atau Purposive Method. Menurut Sugiyono, (2011), metode Purposive adalah suatu metode pemilihan lokasi yang dilakukan dengan sengaja dengan pertimbangan tertentu. Pemilihan lokasi penelitian di daerah Desa Pontang, Kecamatan Ambulu, Kabupaten Jember dengan alasan wilayah tersebut miliki pertanian yang maju, terdapat regu tanam wanita yang terdiri dari buruh tani wanita dan petani wanita di desa tersebut, dan sebagian besar buruh tani di desa tersebut telah berkeluarga.

Penelitian ini dilakukan dengan pendekatan kualitatif. Pendekatan kualitatif merupakan suatu metode yang digunakan dalam pengumpulan data dan terfokus pada fenomena yang melibatkan suatu pendekatan terhadap setiap pokok permasalahan (Rukin, 2019). Penentuan informan menggunakan teknik purposive sampling dengan pertimbangan tertentu. Jumlah informan pada penelitian ini yaitu berjumlah 15 informan yang terdiri dari 10 buruh tani wanita, 4 suami buruh tani wanita, dan 1 anak dari salah satu buruh tani wanita. Pengumpulan data dilakukan dengan metode wawancara mendalam, observasi, dan studi dokumentasi.

Analisis data yang dilakukan dengan menggunakan analisis Harvard atau Gender Framework AnalysisI (GFA). Menurut Overholt dalam Handayani \& Sugiarti, (2008), analisis Harvard merupakan analisis yang digunakan untuk melihat suatu profil gender dari suatu kelompok sosial dan peran gender dalam proyek pembangunan. Analisis Harvard memerlukan tiga komponen dan interelasi satu sama lain, yang meliputi profil aktivitas, profil akses, dan profil kontrol. Aktivitas dikelompokan menjadi tiga yaitu Produktif, Reproduktif, dan Sosial. Profil akses dan kontrol meliputi akses dan kontrol terhadap sumber daya dan akses dan kontrol terhadap manfaat.

Penggalian data di lapangan dengan menggunakan analisis Miles dan Huberman. Metode analisis Miles dan Huberman dilakukan pada saat pengumpulan data berlangsung atau pada saat di lapang. Model analisis Miles dan Huberman dilakukan melalui beberapa tahapan yang meliputi reduksi data, penyajian data, dan penarikan kesimpulan atau verifikasi.

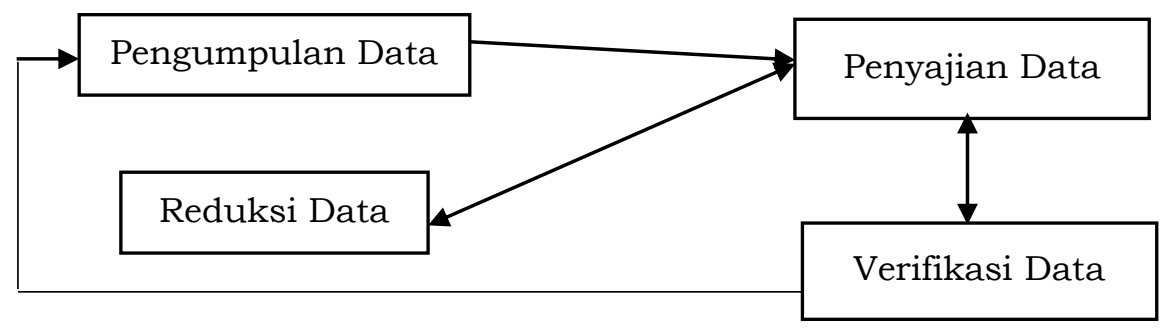

Gambar 1. Model Tahapan Analisis Miles dan Huberman 
Uji keabsahan data dalam penelitian ini menggunakan teknik pengujian triangulasi sumber. Triangulasi teknik digunakan untuk menguji kredibilitas data yang dilakukan dengan cara mengecek data kepada sumber yang sama dengan teknik yang berbeda. Teknik pengumpulan data yang digunakan dalam penelitian ini adalah wawancara, observasi dan studi dokumen. Triangulasi sumber dilakukan dengan cara mengecek data yang telah didapatkan dari beberapa sumber, dalam penelitian ini sumber yang digunakan yaitu anggota keluarga yang terdiri dari istri, suami, dan anak.

\section{HASIL DAN PEMBAHASAN}

\section{Peran Gender Keluarga Buruh Tani Wanita di Regu Tanam Mulyo Asri Desa Pontang Kecamatan Ambulu Kabupaten Jember}

Menurut Wiliam-de Vries, (2006), peran gender merupakan peran yang diciptakan oleh masyarakat untuk laki-laki dan perempuan. Peran gender dapat berubah-ubah dalam waktu, kondisi, dan tempat yang berbeda sehingga dapat dipertukarkan antara peran dari laki-laki dan wanita, seperti peran dalam mengurus anak, mencari nafkah, mengerjakan pekerjaan rumah tanggal, dan lain sebagainya dapat dikerjakan oleh laki-laki ataupun wanita sehingga dapat ditukar tempat tanpa menyalahi kodrat. Menurut Mosse, (1996) peran gender meliputi peran produktif, peran reproduktif, dan peran sosial. Menurut Sukesi, Rosalinda, \& Hartati, (2017), Peran Produktif ialah suatu pekerjaan yang menghasilkan barang dan jasa untuk dikonsumsi dan diperjual belikan. Peran Reproduktif adalah peran yang dilakukan oleh seseorang untuk melakukan kegiatan yang terkait dengan pemeliharaan sumber daya dan tugas rumah tangga seperti contohnya yaitu belanja, menyiapkan makanan, mengumpulkan air, mengasuh dan mendidik anak, dll. Peran Sosial merupakan peran yang terkait dengan kegiatan jasa dan partisipasi politik.

Pada keluarga buruh tani di Desa Pontang yang bergabung dengan regu tanam Mulyo Asri terdapat peran yang mencangkup peran produktif sebagai buruh tani, peran reproduktif sebagai seorang ibu dan istri, peran sosial di sekitar lingkungannya. Adanya peran tersebut tentunya menghasilkan pembagian kerja dalam keluarga buruh tani wanita. Pada keluarga buruh tani wanita di Desa Pontang terdapat kegiatan produktif, reproduktif, dan sosial. Kegiatan produktif yang dilakukan oleh keluarga buruh tani meliputi aktivitas produktif pada tanaman padi, jagung, kacang panjang, buncis, dan cabai yang terdiri dari kegiatan penanaman, pemupukan, penyemprotan, hingga kegiatan pemanenan. Kegiatan reproduktif yang dilakukan keluarga buruh tani yaitu memasak, mencuci, belanja, membersihkan rumah, dan mengurus anak. Kegiatan sosial dalam keluarga buruh tani wanita yaitu meliputi pengajian, hajatan, pertemuan kelompok, dan gotong royong. Untuk mengetahui aktivitas keluarga buruh tani wanita selengkapnya dapat dilihat pada Tabel 1.

Tabel 1. Aktivitas Keluarga Buruh Tani Wanita

\begin{tabular}{lccc}
\hline \multicolumn{1}{c}{ Aktivitas } & Suami & Istri & Anak \\
\hline 1. Aktivitas Produktif & & \\
\hline $\begin{array}{l}\text { Aktivitas Produktif Padi, } \\
\text { Jagung, dan Cabai }\end{array}$ & $\sqrt{ }$ & \\
$\begin{array}{l}\text { Pengolahan Tanah } \\
\text { Penanaman }\end{array}$ & & $\sqrt{ }$ \\
Pemupukan & $\sqrt{ }$ &
\end{tabular}




\begin{tabular}{|c|c|c|c|}
\hline Aktivitas & Suami & Istri & Anak \\
\hline Penyemprotan & $\sqrt{ }$ & & \\
\hline Pemanenan & & $\sqrt{ }$ & \\
\hline \multicolumn{4}{|l|}{ Aktivitas Produktif Kacang } \\
\hline Penanaman & & $\sqrt{ }$ & \\
\hline Pemupukan & $\sqrt{ }$ & & \\
\hline Penyemprotan & $\sqrt{ }$ & & \\
\hline Pemanenan & & $\sqrt{ }$ & \\
\hline Pesortiran & & $\sqrt{ }$ & \\
\hline $\begin{array}{l}\text { Aktivitas Produktif } \\
\text { Mencari Rumput }\end{array}$ & $\sqrt{ }$ & & \\
\hline \multicolumn{4}{|l|}{ 2. Aktivitas Reproduktif } \\
\hline Memasak & & $\sqrt{ } \sqrt{ }$ & \\
\hline Belanja & & $\sqrt{ }$ & \\
\hline Membersihkan Rumah & $\sqrt{ }$ & $\sqrt{ } \sqrt{ }$ & $\sqrt{ }$ \\
\hline Mencuci & & $\sqrt{ }$ & \\
\hline Mengurus Anak & $\sqrt{ }$ & $\sqrt{ } \sqrt{ }$ & \\
\hline \multicolumn{4}{|l|}{ 3. Aktivitas Sosial } \\
\hline Pengajian & $\sqrt{ }$ & $\sqrt{ }$ & \\
\hline Hajatan & $\sqrt{ }$ & $\sqrt{ } \sqrt{ }$ & \\
\hline Pertemuan Kelompok & & $\sqrt{ }$ & \\
\hline Gotong Royong & $\sqrt{ }$ & $\sqrt{ }$ & \\
\hline
\end{tabular}

\section{a. Aktivitas Produktif Keluarga Buruh Tani yang Bergabung dengan Regu Tanam Mulyo Asri di Desa Pontang}

Menurut Sukesi et al., (2017), peran produktif yaitu pekerjaan yang menghasilkan suatu barang ataupun jasa untuk dikonsumsi dan diperjual belikan. Peran produktif dapat memperlihatkan pembagian kerja dan perbedaan tanggung jawab antara laki-laki dan perempuan. Dalam keluarga buruh tani wanita terdapat pembagian kerja pada peran produktif, pembagian kerja tersebut sangatlah terlihat jelas. Aktivitas produktif yang dilakukan oleh suami pada keluarga buruh tani meliputi aktivitas pengolahan tanah, pemupukan, penyemprotan, dan aktivitas mencari rumput, hal tersebut seperti yang dikatakan oleh Ibu Semi:

"iya laki-laki, soale dicampur sama air sekarang kan ngirit ngemes, emes kan mahal sekarang pokok ya biasanya itu laki-laki ngemes tiap 7 hari atau 10 hari gitu ngemes. Mes harganya $5 \mathrm{~kg} \mathrm{150...”}$

Berdasarkan pernyataan dari Ibu Semi, dapat diketahui bahwa pemupukan merupakan salah satu aktivitas yang dilakukan oleh suami pada keluarga buruh tani. aktivitas tersebut dilakukan oleh laki-laki kerena laki-laki dirasa lebih kuat dalam mengerjakannya.

Aktivitas produktif yang dilakukan oleh istri meliputi aktivitas penanaman, pemanenan, dan penyortiran. Hal tersebut sesuai dengan yang dikatakan oleh Ibu Misinah:

"10 orang, orang ketika tanam ya sehari dapat setengah (hektar) gitu kadang-kadang paling lama jam 5, jam 5 baru pulang (Ibu Misinah: 27/9/2020) 
Berdasarkan pernyataan dari Ibu Misinah, dapat diketahui bahwa salah satu aktivitas dalam keluarga buruh tani yang dilakukan oleh istri yaitu aktivitas penanaman. Aktivitas yang dilakukan oleh istri tersebut lebih mementingkan ketelitian dan ketekunan. Para istri biasanya bekerja dari pagi hingga sore hari.

Kegiatan produktif yang dilakukan oleh keluarga buruh tani wanita di Desa Pontang tersebut lebih didominasi oleh suami, hal tesebut dikarenakan suami merupakan kepala keluarga yang memiliki kewajiban untuk menafkahi keluarganya. Meskipun demikian, istri juga turut andil dalam peran produktif sebagai buruh tani wanita untuk membantu meringankan beban suami dan meningkatkan perekonomian keluarga. Hal tersebut senada dengan penelitian yang dilakukan oleh Suparman, (2017), dimana pada penelitian tersebut istri ikut mengambil peran dalam kegiatan produktif, hal ini dilakukan agar dapat mencukupi kebutuhan hidup sehari-hari. Istri ikut bekerja dikarenakan berbagai faktor yang meliputi pendapatan suami tidak dapat mencukupi kebutuhan keluarga, di lingkungan sekitar banyak membutuhkan tenaga buruh tani, pendidikan yang rendah, serta tidak memiliki keterampikan khusus dibidang lain.

\section{b. Aktivitas Reproduktif Keluarga Buruh Tani yang Bergabung dengan Regu} Tanam Mulyo Asri di Desa Pontang

Menurut Sukesi et al., (2017), peran reproduktif yaitu peran yang dilakukan oleh seseorang untuk melakukan kegiatan terkait dengan pemeliharaan sumberdaya dan tugas rumah tangga. Dalam keluarga buruh tani wanita di Desa Pontang tentunya terdapat peran reproduktif. Aktivitas reproduktif yang dilakukan keluarga buruh tani wanita lebih dominan dilakukan oleh istri, hal tersebut dikarenakan istri lah yang memiliki tanggung jawab untuk mengurus keluarganya. Peran atau aktivitas reproduktif yang dilakukan keluarga buruh tani wanita tersebut meliputi memasak, belanja, membersihkan rumah, mencuci, mengasuh anak. Hal tersebut seperti yang dinyatakan oleh Ibu Semi:

"iya bersih-bersih, alah kalau bersih-bersih rumah itu pagi jam 6 sudah berangkat sampai jam 10 jam 1 berangkat, saya bersih bersih rumah ya sak sempete" (Ibu Semi: 8/10/2020)

“iyaa bapak paling ya bantu nyapu-nyapu” (Ibu Semi: 8/10/2020)

Berdasarkan keterangan yang disampaikan oleh Ibu Semi, menunjukan bahwa kegiatan atau aktivitas reproduktif lebih didominasikan oleh istri, dikarenakan seorang istri memiliki tugas dan kewajiban untuk mengurus rumah tangga mereka. aktivitas reproduktif yang dilakukan oleh keluarga buruh tani wanita meliputi kegiatan memasak, belanja, membersihkan rumah, mencuci, dan mengurus anak. Hal ini sesuai dengan penelitian yang diteliti oleh Meliala, W et al., (2019), kegiatan reproduktif pada keluarga petani lebih banyak dilakukan oleh wanita (istri) dibandingkan dengan laki-laki (suami). Walaupun istri tetap berperan dalam kegiatan produktif, tetapi mereka tidak melupakan tugas dan tanggung jawab seperti mengatur dan mengurus rumah tangga, memasak, membersihkan rumah, dan lain sebagainya. 


\section{c. Aktivitas Sosial Keluarga Buruh Tani yang Bergabung dengan Regu Tanam Mulyo Asri di Desa Pontang}

Menurut Sukesi et al., (2017), peran sosial yaitu peran yang terkait dengan kegiatan jasa dan partisipasi politik. Aktivitas sosial dapat dilakukan baik istri ataupun suami. Dalam keluarga buruh tani wanita, aktivitas sosial sering sekali dilakukan, tersebut merupakan suatu bentuk pastisipasi keluarga buruh tani wanita dalam kegiatan masyarakat di Desa Pontang. Aktivitas sosial yang dilakukan tersebut yaitu seperti pengajian rutin, acara hajatan, pertamuan kelompok regu tanam Mulyo Asri, dan gotong royong. Kegiatan atau aktivitas sosial pada keluarga buruh tani wanita di Desa Pontang tersebut lebih dominan dilakukan oleh istri, meskipun demikian aktivitas sosial terkadang juga dilakukan oleh suami. Hal tersebut sesuai dengan pernyataan dari Ibu Supiyah:

"ya kalau kenal ya berdua, kalau gak kenal ya 1 yang becek (hajatan)".

"sering ibu yang becek (hajatan), besok ini ditempatnya bu ida ada sunatan" (Ibu Dwi: 7/10/2020)

Berdasarkan pernyataan dari Ibu Supiyah, menunjukan bahwa kegiatan atau aktivitas sosial pada keluarga buruh tani wanita di Desa Pontang tersebut lebih dominan dilakukan oleh istri, meskipun demikian aktivitas sosial terkadang juga dilakukan oleh suami. Aktivitas sosial yang dilakukan oleh keluarga buruh tani wanita meliputi kegiatan pengajian, hajatan, pertemuan kelompok, dan gotong royong. Hal tersebut sesuai dengan penelitian yang diteliti oleh Puspitasari, (2019), dimana dalam keluarga buruh pabrik karet terdapat jumlah waktu kegiatan pada aktivitas sosial yang menunjukan bahwa istri lebih dominan melakukan aktivitas sosial dibandingkan dengan suami. Di beberapa kegiatan sosial suami dan istri mendapatkan kesempatan yang sama. Aktivitas sosial pada keluarga buruh pabrik karet meliputi kegiatan pengajian, arisan, dan hajatan.

Berbagai kegiatan yang dilakukan pada keluarga buruh tani wanita tentunya memiliki jumlah waktu kegiatan yang berbeda-beda antara suami, istri, dan anak. Jumlah waktu kegiatan yang dilakukan dapat dilihat pada Tabel 2.

Tabel 2. Kegiatan dan Jumlah Waktu Kegiatan dalam Keluarga Buruh Tani di Desa Pontang

\begin{tabular}{|c|c|c|c|c|}
\hline \multirow{2}{*}{ No } & \multirow{2}{*}{ Jenis Kegiatan } & \multicolumn{3}{|c|}{ Jumlah Waktu Kerja(Jam/Hari) } \\
\hline & & Suami & Istri & Anak \\
\hline \multirow[t]{8}{*}{1} & Aktivitas Produktif & & & \\
\hline & Pengolahan Tanah & $8-9$ & & \\
\hline & Penanaman & & $8-9$ & \\
\hline & Pemupukan & $8-9$ & & \\
\hline & Penyemprotan & $8-9$ & & \\
\hline & Pemanenan & & $8-9$ & \\
\hline & Penyortiran & & $8-9$ & \\
\hline & Mencari R umput & $1-2$ & & \\
\hline
\end{tabular}




\begin{tabular}{clccc}
\hline \multirow{2}{*}{ No } & \multicolumn{1}{c}{ Jenis Kegiatan } & \multicolumn{3}{c}{ Jumlah Waktu Kerja(Jam/Hari) } \\
\cline { 3 - 5 } & \multicolumn{2}{c}{ Suami } & Istri & Anak \\
\hline 2 & $\begin{array}{l}\text { Aktivitas Reproduktif } \\
\text { Membersihkan rumah, Mencuci, }\end{array}$ & 1 & & \\
& $\begin{array}{l}\text { Memasak, Belanja, Mengurus } \\
\text { anak }\end{array}$ & & & $1-2$ \\
3 & $\begin{array}{l}\text { Aktivitas Sosial } \\
\text { Pengajian, Perkumpulan, } \\
\text { Hajatan, Gotong royong }\end{array}$ & $1-2$ & $2-3$ & \\
\hline & Total & $10-14$ & $16-19$ & $1-2$ \\
\hline
\end{tabular}

Sumber: Data Primer 2020

Berdasarkan Tabel 2. dapat diketahui bahwa istri memiliki jumlah waktu yang lebih banyak jika dibandingkan dengan suami dan anak yaitu berkisar antara 16-19 jam, sedangkan suami memiliki jumlah waktu berkisar antara 10-14 jam, dan anak memiliki jumlah waktu kegiatan berkisar 1-2 jam. Suami dan istri memiliki jumlah waktu yang sama, namun isrti memiliki tambahan waktu pada kegiatan reproduktif dan kegiatan sosial. Pembagian kerja yang dilakukan oleh keluarga buruh tani wanita menimbulkan dua pandangan yaitu dari segi emik dan segi etik. Menurut pandangan emik merupakan suatu hal yang lumrah terjadi disana. Pandangan emik ini merupakan suatu pandangan yang dikaji dari segi masyarakat diwilayah tersebut. Pandangan emik ini dirasa wajar diwilayah penelitian yaitu di Desa Pontang, hal itu dikarenakan keikutsertaan istri dalam bekerja bertujuan untuk membantu suami dalam meningkatkan perekonomian keluarga, dan istri pun melakukan tanpa adanya paksaan dari berbagai pihak.

Menurut pandangan etik hal tersebut dapat memunculkan isu gender yang terjadi pada keluarga buruh tani wanita. Pandangan etik merupakan pandangan yang dikaji dari kacamata peneliti. Peneliti telah mengumpulkan berbagai data mengenai profil pembagian kerja dan melihat bahwa didalam keluarga buruh tani wanita ini terdapat isu gender yaitu timbulnya beban ganda atau beban kerja yang lebih berat yang dirasakan oleh istri. Menurut Wiliam-de Vries, (2006), beban ganda atau beban kerja berlebih yang dirasakan oleh wanita terjadi ketika wanita memiliki suatu kegiatan atau pekerjaan di luar rumah, namun masih terbebani dengan tugas dan pekerjaannya di dalam rumah tangganya. Pada keluarga buruh tani wanita, istri lebih banyak mengeluarkan waktunya dibandingkan dengan suami. istri tidak hanya menjalankan pekerjaan atau kewajibannya dalam mengurus keluarga (reproduktif) dan sosial, tetapi istri juga turut membantu suami dalam kegiatan produktif agar dapat meringankan beban suami dalam mencari nafkah untuk keluarga. Dalam kesehariannya istri dituntut untuk bangun lebih awal dan bergegas menyiapkan makanan untuk keluarga sebelum berangkat bekerja dan ketika pulang dari bekerja istri melanjutkan pekerjaan rumah seperti membersihkan rumah, mencuci, dan memasak untuk makan malam keluarganya.

\section{Relasi Gender dalam Keluarga Buruh Tani Wanita yang Tergabung dalam Regu Tanam Mulyo Asri di Desa Pontang Kecamatan Ambulu Kabupaten Jember}

Relasi gender merupakan hubungan sosial yang terjalin antara laki-laki dan wanita yang dibentuk secara sosial dan budaya. Dalam keluarga buruh tani wanita tentunya terdapat relasi yang terjalin didalamnya antara suami, istri, dan anak. 
Menurut Handayani \& Sugiarti, (2008), relasi gender yang terjalin antara laki-laki dan wanita menitik beratkan pada profil gender. Relasi yang terjalin tersebut berupa akses dan kontrol mengenai sumberdaya serta manfaatnya. Akses dan kontrol yang dimaksud yaitu akses yang dimiliki suami, istri, dan anak terhadap sumberdaya produktif, kontrol apa yang mereka punya terhadap sumberdaya tersebut, dan siapa yang mendapatkan keuntungan atau manfaat dari penggunaan sumberdaya tersebut. Menurut Handayani \& Sugiarti, (2008) sumberdaya produktif tersebut seperti tanah, hutan, peralatan, pekerja, kredit/modal, pendidikan atau pelatihan. Profil akses dan kontrol terhadap sumberdaya dalam keluarga buruh tani wanita meliputi sumberdaya peralatan, sumberdaya kendaraan (sepeda/motor) dan sumberdaya modal. Manfaat yang diperoleh dari sumberdaya tersebut meliputi penghasilan dan pemenuhan kebutuhan dasar. Data selengkapnya mengenai profil akses dan kontrol terhadap sumberdaya dan manfaat dapat dilihat pada Tabel 3 .

Tabel 3. Akses dan Kontrol terhadap Sumberdaya dan Manfaat pada Keluarga Buruh Tani Wanita

\begin{tabular}{|c|c|c|c|c|c|c|}
\hline \multirow{2}{*}{ Akses dan Kontrol } & \multicolumn{2}{|c|}{ Suami } & \multicolumn{2}{|c|}{ Istri } & \multicolumn{2}{|c|}{ Anak } \\
\hline & Akses & Kontrol & Akses & Kontrol & Akses & Kontrol \\
\hline $\begin{array}{ll}\text { A. } & \text { Sumberdaya } \\
\text { - } & \text { Peralatan } \\
- & \text { Arit } \\
- & \text { Kantongan } \\
- & \text { Sarung Tangan } \\
- & \text { Pacul }\end{array}$ & $\sqrt{ }$ & $\sqrt{ } \sqrt{ }$ & $\sqrt{ }$ & & & \\
\hline $\begin{array}{l}\text { - Sepeda/Motor } \\
\text { - Modal }\end{array}$ & $\begin{array}{l}\sqrt{ } \\
\sqrt{ }\end{array}$ & $\begin{array}{l}\sqrt{ } \sqrt{ } \\
\sqrt{ }\end{array}$ & $\begin{array}{l}\sqrt{ } \\
\sqrt{ }\end{array}$ & $\sqrt{ }$ & & \\
\hline $\begin{array}{l}\text { B. Manfaat } \\
\text { - Penghasilan } \\
\text { - Pemenuhan } \\
\text { Kebutuhan Dasar } \\
\text { (Sandang, Pangan, } \\
\text { Papan) }\end{array}$ & $\begin{array}{l}\sqrt{ } \\
\sqrt{ }\end{array}$ & $\sqrt{ }$ & $\begin{array}{l}\sqrt{ } \\
\sqrt{ }\end{array}$ & $\begin{array}{l}\sqrt{ } \sqrt{2} \\
\sqrt{ } \sqrt{ }\end{array}$ & $\begin{array}{l}\sqrt{ } \\
\sqrt{ }\end{array}$ & \\
\hline
\end{tabular}

Akses dan kontrol terhadap sumberdaya pada keluarga buruh tani wanita tersebut lebih dominan dilakukan oleh suami. Suami mengkontrol sumberdaya seperti peralatan dan kendaraan (sepeda atau motor). Pengkontrolan terhadap sumberdaya dilakukan suami seperti melakukan perbaikan peralatan ataupun kendaraan. Hal ini seperti yang dikatakan oleh Bapak Sunarto:

"yo neng bengkel gitu lek rusak disel kalau tengki gitu kalau ya arit rusak benerin sendiri" (Bapak Sunarto: 6/10/2020)

Pernyataan lainnya disampaikan oleh Ibu Parti:

"bocor nanti ditambalkan, bapak yang biasa nambalkan di bengkel" (Ibu Parti: 7/ 10/2020) 
Selain mengkontrol sumberdaya peralatan dan kendaraan, suami juga berhak mengakses atau menggunakan sumberdaya tersebut sama halnya dengan istri. Sumberdaya modal yang digunakan untuk membeli peralatan atau kebutuhan dalam aktivitas produktif tersebut suami dan istri bekerja sama dalam mengkontrol serta mengakses sumberdaya modal. Seperti yang dikatakan oleh Bapak Ngatemo:

"modal sendiri. Juragan gak minjemin, ya kalau abis dapat upah nek gak duwe arit ta apa gitu ya beli pake uang itu." (Bapak Ngatemo: 4/11/2020)

Akses dan kontrol terhadap manfaat dalam keluarga buruh tani wanita ini lebih dominan dilakukan oleh istri. pengontrolan manfaat yang dilakukan istri tersebut meliputi penghasilan dan juga pemenuhan kebutuhan dasar. Seperti yang dikatakan oleh Ibu Parti:

"ya gak janji ini aja sehari itu 40,45 kalau manen lombok ini. Kalau kerja harian sekarang 50 sudah naik sekarang sehari sampai beduk itu tarus istrirahat nanti pulangnya jam 4. Kalau manen lombok sekarang lombok murah dapatnya ya gak mesti dapat sehari ya 30, 35 itu kalau manen lombok kalau manen buncis ya sehari 50. Iyaa ibu yang ngatur uangnya" (Ibu Parti: 7/10/2020)

Istri merupakan pemegang ekonomi terkuat dalam keluarga namun bukan berarti istri menguasai manfaat yang ada, istri juga melakukan pembagian dengan suami dan anaknya. Pembagian yang dimaksud disini yaitu ketika suami ataupun anak membutuhkan uang untuk membeli kepertuan mereka, istri memberikan uang sesuai dengan yang mereka butuhkan. Manfaat yang didapatkan dari sumberdaya tersebut tentunya akan dinikmati oleh seluruh anggota keluarga buruh tani wanita di Desa Pontang.

\section{KESIMPULAN}

Terdapat pembagian peran pada keluarga buruh tani wanita, pembagian kerja tersebut meliputi aktivitas produktif, aktivitas reproduktif, dan aktivitas sosial. Aktivitas produktif ini dilakukan oleh suami dan istri. Kegiatan reproduktif dominan dilakukan oleh istri, namun terkadang suami dan anakpun turut membantu mengerjakan aktivitas tersebut. Kegiatan sosial dilakukan oleh suami dan istri, namun lebih dominan dilakukan oleh istri.

Relasi yang terjalin dalam keluarga buruh tani wanita berupa adanya akses kontrol terhadap sumberdaya dan manfaat. Suami lebih dominan dalam mengontrol sumberdaya seperti peralatan dan kendaraan, namun suami juga tetap dapat mengakses sumberdaya tersebut seperti halnya istri, sedangkan akses dan kontrol terhadap sumberdaya modal untuk membeli peralatan dilakukan oleh suami dan istri. dalam akses dan kontrol terhadap manfaat istri lah yang lebih dominan dalam mengontrol manfaat. Istri mengontrol perihal pendapatan dan juga pemenuhan sandang, pangan, dan papan. Manfaat yang telah didapat tersebut juga dapat diakses atau dinikmati oleh seluruh anggota keluarga. 
Adanya pembagian peran dan relasi pada keluarga buruh tani wanita, teori gender terdapat dua pandangan yaitu pandangan emik dan pandangan etik. Dalam pandangan emik keikutsertaan istri dalam bekerja merupakan sesuatu yang wajar dan sering terjadi di daerah penelitian sehingga tidak terjadi konflik dalam keluarga ataupun di lingkungan sekitar. Dalam pandangan etik, terdapat isu gender yang terjadi dalam keluarga buruh tani wanita. Isu gender yang dimaksud yaitu adanya beban kerja yang lebih berat yang dialami oleh istri.

Kekurangan dari hasil penelitian ini yaitu belum adanya kepedulian gender dari suami dengan membantu istri dalam meringankan beban kerja ganda mereka dan kurangnya komunikasi antara istri dengan anggota keluarga jika dirasa beban kerja istri lebih banyak sehingga memerlukan bantuan dari anggota keluarga lainnya. Kelebihan dari hasil penelitian ini yaitu tidak adanya konflik yang ditimbulkan perihal permasalahan gender di keluarga maupun di masyarakat lingkungan penelitian sehingga hubungan yang terjalin tetap harmonis.

\section{DAFTAR PUSTAKA}

Handayani, T., \& Sugiarti. (2008). Konsep dan Teknik Penelitian Gender. Malang: UMM Press.

Harahap, I, P, A., Rosnita, \& Yulida, R. (2016). Curahan Waktu Wanita Tani dan Kontribusinya terhadap Pendapatan Keluarga di Desa Muara Lembu Kecamatan Singingi Kabupaten Kuantan Singingi. Jom Faperta, 2(1), 1-10.

Manyamsari, I., \& Mujiburrahmad. (2014). Karakteristik Petani dan Hubungannya dengan Kompetensi Petani Lahan Sempit. Agrisep, 15(2), 58-74.

Meliala, W, S., Harmona, D., \& Humaizi. (2019). Gender Analysis of Women Farmers (Case Study of Corn Farmers in Tigabinanga District Tigabinanga Subdistrict Karo). International Jurnal of Multicultural and Multireligious Understanding, $6(4), 115-124$.

Mosse, J. C. (1996). Gender dan Pembangunan. Yogyakarta: Pustaka Pelajar.

Puspitasari, A. T. (2019). Peran Gender dan Strategi Bertahan Hidup Keluarga Buruh Pabrik Untuk Memenuhi Kebutuhan Keluarga (Studi kasus di Pabrik Karet PTPN XII Kebun Mumbul Kecamatan Mumbulsari Kabupaten Jember. Universitas Jember.

Rukin. (2019). Metodologi Penelitian Kualitatif. Takalar: Yayasan Ahmar Cendekia Indonesia.

Sintia, S., \& Mardhiah, D. (2020). Relasi Sosial dalam Keluarga Buruh Tani di Desa Tanjung Pauh Mudik Kecamatan Keliling Danau Kabupaten Kerinci. Jurnal Perspektif, 3(2), 348-355.

Sugiyono. (2011). Metode Penelitian Kuantitatif Kualitatif dan R\&D. Bandung: Alfabeta.

Sukesi, K., Rosalinda, H., \& Hartati, A. S. (2017). Migrasi Wanita, Remitansi dan Perubahan Sosial Ekonomi Pedesaan. Malang: UB Press.

Suparman. (2017). Peran Ganda Istri Petani Studi Kasus di Desa Perangian Kecamatan Baraka Kabupaten Enrekang. Jurnal Pendidikan, 1(2), 104-114.

Suratiyah, K. (2015). Ilmu Usaha Tani. Jakarta: Penebar Swadaya.

Wiliam-de Vries, D. (2006). Gender Bukan Tabu Catatan Perjalanan Fasilitasi Kelompok Wanita di Jambi. Bogor: Center of Internasional Forestry Research. 